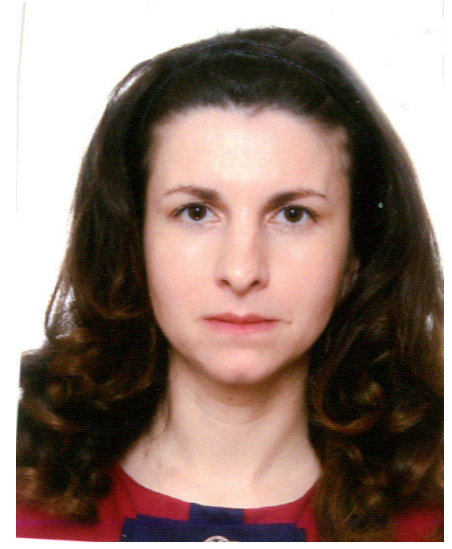

Маріанна Леврінц,

кандидат педагогічних наук, доцент кафедри філологічних дисциплін, Закарпатський угорський інститут ім.Ракоці Ференца II, (м.Берегово, Україна)

\section{Marianna Levrints,}

$\mathrm{PhD}$ in Education, Associate Professor,

Department of Philology,

Ferenc Rákóczi II Transcarpathian Hungarian Institute, (Beregovo, Ukraine)

marianna@kmf.uz.ua

ORCID ID: 0000-0002-2206-7113

УдК : 371.3:811.111: Л:86

\title{
ГУМАНІЗМ ЯК КОНЦЕПТУАЛЬНА ОСНОВА ФАХОВОЇ ПІДГОТОВКИ ВЧИТЕЛІВ ІНОЗЕМНИХ МОВ У США
}

\begin{abstract}
Анотація. Філософія гуманізму становить методологічну основу американської освітньої системи. Проте особливості впливу теоретико-філософських положень гуманізму на фахову підготовку вчителів IM (іноземних мов) у США досліджені недостатньо. Мета статті полягає у вивченні концептуальних положень теорії гуманізму, у виявленні її впливу на підготовку вчителів IM у США та у визначенні її місця і ролі в американській системі підготовки вчителів ІМ. Дослідження виконане із застосуванням методів аналізу, інтерпретації науково-практичного доробку, синтезу, класифікації, порівняння, за допомогою яких здійснюється співставлення теоретичних та практичних підходів до підготовки педагогічних фахівців у галузі IM, узагальнення передового досвіду, представленого у працях американських освітян.

Проведене нами дослідження засвідчило, що основоположні ідеї філософії гуманізму щодо формування цілісної особистості педагога лежать в основі американської системи підготовки вчителів, залишаючись надзвичайно актуальними й нині. У вузькому розумінні гуманізм розглядається як підхід до фахової підготовки вчителів (humanistic based teacher education) у системі педагогічної освіти США. У ширшому сенсі гуманізм становить концептуальну основу фахової підготовки вчителів, засадничий принцип філософії освіти, а також важливу науково-практичну проблему. Першочергове завдання системи педагогічної освіти у розрізі гуманізму становить всебічний розвиток особистості педагога. Цінностями гуманістичної освіти є турбота про людську гідність, автономність, рівноправність і належність. Оптимізація педагогічної освіти передбачає, поряд із формуванням професійних знань та компетентностей, розвиток професійно значущих особистісних якостей майбутніх учителів, педагогічно доцільних форм взаємодії та стосунків між учасниками навчального процесу. У світлі гуманістичного підходу відбувається перегляд ролей учителя, місією якого є фасилітація навчання, тобто сприяння у виявленні учнями власних інтересів, здібностей, автономності тощо.

У прикладній лінгвістиці переосмислення теоретико-практичного доробку гуманізму втілюється в оновленні підходів до викладання IM, було запропоновано конкретні навчальні технології, методи і прийоми навчання, які міцно прижились у методичному репертуарі. На нашу думку, майбутні вчителі ІМ, більшість із яких є ознайомленими із засадами гуманізму, мають реалістичне уявлення щодо їх реалізації в навчальному процесі, на відміну від студентів інших спеціальностей. Подальшими перспективами дослідження вважаємо емпіричну перевірку доцільності реалізації гуманістичних принципів у підготовці вчителів IM.
\end{abstract}

Ключові слова: гуманізм, підготовка вчителів, іноземні мови, система педагогічної освіти США.

\section{HUMANISM AS A CONCEPTUAL FOUNDATION OF FOREIGN LANGUAGE TEACHER EDUCATION IN THE USA}

Abstract. Humanistic philosophy is one of the foundational elements of the American educational system's methodology. Nevertheless, the problem of influence of theoretical-philosophical underpinnings of humanism on foreign language teacher education is underrepresented in the relevant academic literature. Thus, the present paper analyses conceptual orientations of the theory of humanism, highlighting its impact on foreign language teacher preparation, as well as its role and place in the American system of teacher education. To this end complementary research methods are applied, such as analysis, synthesis, interpretation, classification, comparison on the basis of which the theoretical and practical approaches to foreign language teacher preparation are elucidated.

The key themes of humanistic philosophy pertaining to the holistic development of prospective teacher's personality and advancement of human potential have been present in the American education for an extended period of time and their values are still widely recognized today. Several planes of analysis of the humanistic teacher education are discernable in the academic literature. In the narrow sense, humanism is viewed as an approach or model in the system of teacher education, generally known 
as humanistic based teacher education. In a wider sense, humanism constitutes the conceptual foundation of teacher education, pivotal principle of educational philosophy and an important theoretical and practical problem. At the fore of humanistic teacher education is the overall development of teacher's personality, self-actualization, autonomy, equity, and sense of belonging. In the humanistic educators' understanding, quality teacher education is not reduced to professional knowledge and profession-related competencies development. One of the major concerns is seen in the development of prospective teachers' personal qualities, pedagogically-sound forms of interaction and relationships among the protagonists of educational process.

In the light of humanistic philosophy reconsideration is given to teachers' roles, whose primary mission is seen in the facilitation of learning, assisting learners in realizing their personal potential, capabilities, interests, bolstering learner autonomy etc. Closely aligned with humanistic education is student-centered paradigm. By the same token, learners are also expected to assume new roles, whereby they are vested with greater responsibility and autonomy in initiating, regulating, and controlling instructional processes.

Gaining foothold in applied linguistics ideas of humanistic education have made their way into the field of foreign language teaching, leading to the reassessment of its current practices and principles. As a result, new methods and techniques have enriched language teaching repertoire. Due to the specific nature of the foreign language as a discipline, key tenets of humanistic education have become deeply rooted among effective instructional practices. In our opinion, most of the prospective foreign language teachers have certain practical experience of engaging with humanistic principles gained in the foreign second/language lessons. Thus, they hold more realistic views with regard to the potentials and pitfalls of incorporating humanistic ideas in the instructional process, as compared to other majors.

Overall, there is general paucity of research convincingly demonstrating the effectiveness of including humanistic tenets in foreign language teacher education, which serves as one of the possible avenues for further research.

Keywords: humanism, humanistic education, teacher education, foreign languages, the system of foreign language teacher education in the USA.

\section{ВСТУП}

Постановка проблеми. Філософсько-епістемологічне сутнісне наповнення педагогічної освіти США визначається сукупністю теоретичних впливів. Багатогранну концептуальну основу системи педагогічної освіти США становлять філософія пост-модернізму, соціалконструктивізму, критичної педагогіки, а також теорія гуманізму. Гуманізм залишається наскрізною лінією світового освітнього дискурсу протягом тривалого часу, визначаючи особливості розвитку освітніх систем та підготовки педагогів. Проте особливості впливу теоретико-філософських положень гуманізму на фахову підготовку вчителів IM вивчається недостатньо. Аналіз джерельної бази засвідчує наявність неоднозначних трактувань та прогалин у вивченні ролі та місця гуманізму в системі підготовки вчителів IM у США. Вважаємо, що вивчення прогресивного зарубіжного досвіду організації підготовки вчителів ІМ у США із виділенням його позитивних напрацювань є важливим кроком на шляху до вдосконалення вітчизняної системи педагогічної освіти.

Аналіз останніх досліджень і публікацій. До вивчення проблеми системи педагогічної освіти США неодноразово звертались як вітчизняні, так і зарубіжні вчені. Системний аналіз проблеми фахової підготовки вчителів у США здійснено в докторських дисертаціях Кошманової Т., Шандрук С. Комплексний аналіз питання підготовки вчителів у США здійснено в працях Задорожної І., Корнієнко В., Ларіної Т., Мукан Н., Нагач Н., Рибачук К., Роман Р., Садовець О., Сисоєвої С., Сулим-Карлір І. тощо. Проблема підготовки фахівців філологічного профілю, зокрема вчителів IM у США, висвітлюється в роботах Бідюк Н., Іконнікової М., Кокор М., Пасинкової І., Тарнопольського О., Черній Л. Масштабний внесок у розробку проблеми підготовки вчителів у США здійснено такими американськими дослідниками, як ДарлінгГемонд Л., Кохран-Сміт М., Зайхнер К., зокрема вчителів IM - Борг С., Нунан Д., Річардс Д., Фріман Д., ЛарсенФріман Д. та ін. Проблеми гуманізму й гуманізації педагогічної освіти розглядаються американськими ученими: Еліас М., Московіц Г., Ло Л., Патерсон Х., Перкі В., Роджерс К., Скотт К. та ін.

МЕТА І ЗАВДАННЯ ДОслІДЖЕННЯ. Мета статті полягає у вивченні концептуальних положень теорії гуманізму, у виявленні її впливу на підготовку вчителів IM у США та у визначенні її місця й ролі в американській системі підготовки вчителів IM.

\section{МЕТОДИ ДОСЛІДЖЕННЯ}

Вирішенню означеної мети сприяли комплементарні теоретичні методи дослідження, зокрема аналіз та інтерпретація науково-практичного доробку з означеної проблеми, методи синтезу, класифікації, порівняння, за допомогою яких здійснювалося співставлення теоретичних та практичних підходів до підготовки педагогічних фахівців у галузі IM, узагальнення передового досвіду, представленого у працях американських освітян.

\section{РЕЗУЛЬТАТИ ДОСЛІДЖЕННЯ}

Гуманізм для американської системи освіти та підготовки вчителів є наріжним каменем, закладеним у їі фундамент в період становлення. За свідченням Купмена Г., філософія гуманізму становить методологічну основу освітньої системи країни, охоплюючи її початковий, середній та вищий щаблі, відображаючись відповідним чином у змісті та навчальних підходах (Koopman G., 1987, р. 238). Найяскравішим прикладом утілення філософії гуманізму у США є прогресивістський освітній рух (progressive education movement), головним ініціатором якого став Джон Дьюї. Вченого також згадують як батька прогресивістської освіти та гуманізму в Америці. Під керівництвом Дьюї Дж. було також засновано Американську гуманістичну спілку (American Humanist Association).

1960-1970х рр. на теренах педагогічної освіти США з новою силою утверджується філософія гуманізму як реакція на біхевіоризм, якому вчені протиставили формування цілісної особистості та зростання особистісного потенціалу (Chen P., \& Schmidtke C., 2017, р.118).

Передумовами, які створили сприятливий ґрунт для розвитку гуманізму, стали соціально-економічні умови повоєнного часу, в яких перебувала країна. Після людських жертв Другої світової війни та Великої депресії у 
1950-60x рр. у США поступово почав наростати соціально-економічний добробут, різко зросла народжуваність, пожвавився інтерес до виховання та освіти молоді (Samuels P., 2013, р. 3). У 1960-70х рр. гуманізм в освіті почав розглядатись як чинник, який може пробудити інтерес учителів та учнів до освіти (Rogers C., \& Freiberg H., 1994; Chen P., \& Schmidtke C., 2017).

Ідеологами та яскравими представниками гуманізму в освіті стали американські науковці Абрагам Маслоу та Карл Роджерс, які вбачали головну мету освіти в розвитку самоактуалізованої особистості. Послідовники гуманізму рішуче засуджують стандартну, механістичну модель освіти із властивими їй звітностями та статистичними вимірюваннями, без урахування індивідуальних потреб і контекстуальних yмов (Law L., 2015). Для гуманістів особистісна самоактуалізація $€$ не менш важливою, ніж навчальна успішність та інтелектуальний розвиток учнів (Moskowitz G., 1978).

Рисами гуманістичної освіти є піклування про людську гідність, автономність, рівноправність. Для того, щоб допомогти учням самоактуалізуватись, учителю необхідно сприяти емоційному та інтелектуальному розвитку учнів, самостійності та самокерованості у навчанні (Elias J., \& Merriam S., 2005).

У розумінні гуманістів особистість учителя є чи не найважливішим чинником, який сприяє забезпеченню продуктивності освітніх процесів. Водночас значна предметна зорієнтованість програм та нівелювання особистісних якостей не сприяє становленню гармонійної самоактуалізованої особистості майбутнього вчителя. Важливість емпірично обґрунтованих дисциплінарних знань є беззаперечною, але якісна педагогічна освіта не може обмежуватись ними. Таким чином, всебічний розвиток особистості педагога в розрізі гуманізму становить першочергове завдання системи педагогічної освіти.

Оптимізація педагогічної освіти передбачає, поряд із формуванням професійних знань та компетентностей, розвиток професійно значущих особистісних якостей майбутніх учителів, педагогічно доцільних форм взаємодії та стосунків між протагоністами навчального процесу. Тому реформування педагогічної освіти передбачає розширення їі цільового компонента за рахунок двох аспектів: 1) підготовка вчителів включає як когнітивний, так і афективний розвиток; 2) розвиток компетентності у майбутніх учителів до діагностування та врахування афективних потреб учнів (Patterson C., \& Purkey W., 1993, p. 152)

У світлі гуманістичного підходу відбувається перегляд ролей учителя, який покликаний виконувати функцію фасилітатора навчання, тобто допомагати учням у виявленні власних інтересів, здібностей, сприяти самокерованості або автономності у навчанні. Вчителю необхідно виявляти повагу до особистості учня, його внутрішнього світу думок і почуттів.

Роль учнів у навчально-виховному процесі також переосмислюється під упливом ідей гуманізму. Внутрішньо споріднені положення гуманізму та студентоцентризму надають учню роль активного учасника, який власноруч ініціює й оцінює навчальну діяльність та успішність, займається самоаналізом з метою самоактуалізації (Stephens G., 2015).

До творчого переосмислення теоретичного доробку гуманізму вдались також прикладні лінгвісти, розробляючи нові підходи до навчання IM і активно втілюючи його принципові положення в практику викладання IM. Саме в галузі лінгводидактики, на відміну від інших освітніх галузей, було запропоновано конкретні навчальні технології, методи і прийоми навчання, які міцно прижились у методичному репертуарі. Власне, для майбутніх учителів IM, які володіють досвідом вивчення IM на засадах гуманізму, принципи гуманістичної освіти $€$ не абстрактними, незрозумілими категоріями, а цілком реальними педагогічними явищами, які наповнюють іншомовне навчальне середовище.

Навчання IM відбувається у студентоцентристській парадигмі, зосереджуючись на афективному та емоційному компонентах навчання, не применшуючи при цьому значення когнітивного аспекту. Навчальний матеріал і техніки обираються з урахуванням ставлення до них учнів, а також до мови, що вивчається, її культури, однокласників, учителя, навчальної ситуації та атмосфери навчального середовища.

Підсумовуючи особливості афективно-гуманістичного підходу, Селс-Мерсіа М. виділяє його наступні характеристики:

а) повага до особистості студента, викладача та світу їх почуттів;

б) особистісно значуще для учня спілкування іноземною мовою;

в) на уроках широко застосовується навчання у групах і парах;

г) класна атмосфера є більш важливою, ніж навчальний матеріал або методи навчання;

д) для успішного навчання необхідні взаємопідтримка та взаємодія між учнями;

ж) навчання IM розглядається як процес самореалізації;

з) вчитель виконує роль порадника або фасилітатора (Celce-Murcia M., 1991, p. 5).

Серед основних методів гуманістичного підходу найбільшою популярністю користувались общинне вивчення мови (Community Language Learning, Curran Ch., 1972), тихий метод (the Silent Way, Gattegno G., 1972) та сугестопедія (Лозанов Д. 1979).

Аналізуючи переваги підходів до викладання IM, заснованих на положеннях гуманізму, Московіц Г. пропонує навчати іноземних мов у спосіб, який дозволяє учням розвивати більш позитивне ставлення до своєї індивідуальності та своїх однокласників, розкривати власні інтереси, підвищувати самоповагу та краще зрозуміти себе. На думку автора, це сприяє зростанню мотивації учнів, а отже, й академічній результативності (Moskowitz G., 1978, p.13). 
Основоположні ідеї філософії гуманізму щодо формування цілісної особистості педагога, як свідчить ретроспективний аналіз, лежать в основі американської системи підготовки вчителів, залишаючись надзвичайно актуальними й нині. Гуманізм знаходить відгук у системі педагогічної освіти США у тому чи іншому вигляді, становлячи засадничий принцип філософії освіти та фахової підготовки педагогів, модель фахової підготовки вчителів (humanistic based teacher education) і важливу науково-практичну проблему.

За свідченням американських дослідників системи педагогічної освіти Роджерса К. і Скотта К., концептуальна зорієнтованість найупливовіших програм фахової підготовки вчителів країни базувалась на гуманістичній та критично-соціальній парадигмах, де фахова підготовка становила єдине ціле із особистісним зростанням. Як приклад, автори називають наступні програми: Банк Стріт коледж (Bank Street College, 1930 період заснування), Програма підготовки вчителів Школа Перспектив (the Prospect School Teacher Education Program, 1968-1990), Новий Коледж Колумбійського педагогічного коледжу (New College (1932-1939) of Columbia Teachers College), Вищий педагогічний навчальний заклад м. Патні (the Putney Graduate School of Teacher Education, 1950-1965). У вищезгаданих програмах особливий акцент робиться на формуванні особистості майбутнього вчителя, самопізнанні, самоусвідомленні та розумінні своєї унікальності. Формування самоусвідомлення й самопізнання здійснювалось із використанням ретроспекції та вивчення минулого досвіду, взаємодії з навколишнім середовищем, спостереженням за поведінкою дітей. Важливою технікою навчання вважалась рефлексія (Rodgers C., \& Scott K., 2008, р. 744-751).

У 70-х рр. XX ст. під впливом теоретичних напрацювань психологів гуманізму в Америці оформлюється підхід до фахової підготовки вчителів, який одержав назву «гуманістично зорієнтована освіта вчителів» (humanistic based teacher education). Принциповою позицією теоретично-практичного підходу стало зосередження на індивідуальності вчителя та його особистісному зростанні. Прихильники гуманістично зорієнтованого підходу протиставляли своє бачення сутності підготовки вчителя компетентнісно зорієнтованому підходу (соmреtеnсуbased teacher education), який мав прескриптивний характер, виділяючи перелік компетенцій і нормативів. Для освітніх гуманістів ключовими є унікальність і гідність індивіда. Тому підготовка вчителів не може обмежуватися формулюванням стандартизованих навчально-професійних компетенцій (Јoусе В., 1975, р. 130-132).

Про популярність проблем, порушених прихильниками гуманізму, свідчить обсяг останніх досліджень, здійснених науковцями країни, у предметному колі яких є становлення особистості педагога [10], гуманізація підготовки вчителів (Patterson C., \& Purkey W., 1993) і т. ін.

На сучасному етапі система педагогічної освіти США продовжує наслідувати гуманістичні традиції, доповнені соціал-критичним філософським баченням. Роджерс К., Скотт К. наступним чином підсумовують фундаментальні принципи, властиві сучасним програмам професійної підготовки педагогів у США: 1) учителі повинні займатися самопізнанням, усвідомлювати власні професійно значущі переконання, цінності та упередженість; 2) учителі повинні критично ставитись до себе, а також усвідомлювати привілеї та несправедливість у власному статусі та становищі учнів; 3) учителям необхідно вивчати свої соціальні перспективи; 4) учителям необхідно рефлексивно розглядати свій навчальний досвід, починаючи з дитинства, та зрозуміти, яким чином цей досвід уплинув на їхні погляди на професію вчителя; 5) учителям необхідно бути обізнаними із поглядами, які відрізняються від власних (Rodgers C., \& Scott K., 2008, р. 749). Спільною місією, яка поєднує програми підготовки вчителів у США, є допомога студентам в особистісному та професійному зростанні, самовизначенні, керуванні мотивацією, формуванні критичного світогляду та професійної позиції (Rodgers C., \& Scott K., 2008, p. 751).

Як окремий підхід у системі освіти країни гуманізм відступає на задній план з низки іноді необґрунтованих причин, а саме:

- через нерозмежування світського гуманізму (громадянський рух у США, який ототожнюється з атеїзмом) і освітнього; деякі батьки виступили проти гуманізму, керуючись релігійними переконаннями та страхом девальвації моральних цінностей;

- представникам гуманізму в освіті, на жаль, не вдалось досягти чіткого формулювання відповідних принципів навчання й виховання, тому питання, яким чином гуманістичний підхід повинен втілюватись у шкільній практиці, залишається відкритим (Chen P., \& Schmidtke C., 2017, p. 120-121).

Зважаючи на тенденційність американської системи освіти до стандартизації, а також першочерговість когнітивного розвитку, зосередженість на афективному компоненті навчання вбачалась контрпродуктивною академічній успішності. Знайшлись навіть ті, хто розгледів загрозу у зверненні до особистості майбутнього вчителя, індивідуалізації, побоюючись, що це призведе до егоїзму та ігнорування вчителями нагальних соціальних проблем.

Гуманістично зорієнтована освіта вчителів як окремий підхід не набула широкої популярності в американській системі педагогічної освіти. Критики підходу зазначали, що підготовка вчителів повинна відбуватись не лише з урахуванням особистісних ресурсів, а й того соціального середовища, в якому відбувається професійне становлення педагогів. Водночас принциповість звернення до особистості майбутнього вчителя, його самоактуалізації та зростання лягли в методологічну основу педагогічної освіти, понині не втрачаючи своєї актуальності.

\section{ВИСНОВКИ ТА ПЕРСПЕКТИВИ ПОДАЛЬШИХ ДОСЛІДЖЕНЬ}

Отже, проведене нами дослідження засвідчило, що основоположні ідеї філософії гуманізму щодо формування цілісної особистості педагога залишаються надзвичайно актуальними й нині. У вузькому розумінні гуманізм розглядається як підхід до фахової підготовки вчителів (humanistic based teacher education) у системі 
педагогічної освіти США. У ширшому сенсі гуманізм становить концептуальну основу фахової підготовки вчителів, засадничий принцип філософії освіти, а також важливу науково-практичну проблему. Першочергове завдання системи педагогічної освіти у розрізі гуманізму становить всебічний розвиток особистості педагога. Цінностями гуманістичної освіти є турбота про людську гідність, автономність, рівноправність. Оптимізація педагогічної освіти передбачає, поряд із формуванням професійних знань та компетентностей, розвиток професійно значущих особистісних якостей майбутніх учителів, педагогічно доцільних форм взаємодії та стосунків між протагоністами навчального процесу. у прикладній лінгвістиці переосмислення теоретикопрактичного доробку гуманізму втілюється в оновленні підходів до викладання IM.

Перспективними напрямами подальших досліджень вважаємо емпіричну перевірку доцільності реалізації гуманістичних принципів у підготовці вчителів IM.

\section{СПИСОК ВИКОРИСТАНИХ ДЖЕРЕЛ}

Celce-Murcia, M. (1991).Teaching English as a second or foreign language (2nd ed.). Boston, Massachusetts: Heinle and Heinle Publishers.

Chen, P., \& Schmidtke, C. (2017). Humanistic Elements in the Educational Practice at a United States Sub-Baccalaureate Technical College. International Journal for Research in Vocational Education and Training, 4, Is. 2, 117-145.

Elias, J., \& Merriam, S. (2005). Philosophical foundations of adult education (3rd ed.). Malabar, FL: Krieger.

Joyce, B. (1975). Conceptions of man and their implications for teacher education. In K. Ryan (Ed.). Teacher education, 74th yearbook of the National Society for the Study of Education. Chicago: University of Chicago Press, 111-145.

Koopman, G. (1987). The Thread of Humanism in the History of American Education. Journal of Curriculum and Supervision., 2, Is.3, $233-247$.

Law, L. (2015). Humanizing education: Teacher leaders influencing pedagogical change (Unpublished doctoral dissertation). lowa State University, lowa.

Moskowitz, G. (1978). Caring and sharing in the foreign language class. Rowley, MA: Newbury House.

Patterson, C., \& Purkey, W. (1993). The preparation of humanistic teachers for next century schools. The Journal of Humanistic Education and Development, 30, 147-155.

Rogers, C., \& Freiberg, H. (1994). Freedom to learn (3rd ed.). New York, NY: Maxwell Macmillan International.

Rodgers, C., \& Scott, K. (2008). The development of the personal self and professional identity in learning to teach/ In Cochran-Smith, M. and Feiman-Nemser Sh., (Eds.) Handbook of Research in Teacher Education. Mahway, NJ: Lawrence Earlbaum, 1, 732 - 755.

Samuels, P. (2013). 20th-Century Humanism and 21st-Century Technology: A Match Made in Cyberspace. English Teaching Forum, 3, 2-19.

Stephens, G. (2015). Uncertified and teaching: Industry professionals in career and technical education classrooms. International Journal for Research in Vocational Education and Training, 2(2), 119-135.

\section{REFERENCES}

Celce-Murcia, M. (1991).Teaching English as a second or foreign language (2nd ed.). Boston, Massachusetts: Heinle and Heinle Publishers.

Chen, P., \& Schmidtke, C. (2017). Humanistic Elements in the Educational Practice at a United States Sub-Baccalaureate Technical College. International Journal for Research in Vocational Education and Training, 4, Is. 2, 117-145.

Elias, J., \& Merriam, S. (2005). Philosophical foundations of adult education (3rd ed.). Malabar, FL: Krieger.

Joyce, B. (1975). Conceptions of man and their implications for teacher education. In K. Ryan (Ed.). Teacher education, 74th yearbook of the National Society for the Study of Education. Chicago: University of Chicago Press, 111-145.

Koopman, G. (1987). The Thread of Humanism in the History of American Education. Journal of Curriculum and Supervision., 2, Is.3, $233-247$.

Law, L. (2015). Humanizing education: Teacher leaders influencing pedagogical change (Unpublished doctoral dissertation). lowa State University, lowa.

Moskowitz, G. (1978). Caring and sharing in the foreign language class. Rowley, MA: Newbury House.

Patterson, C., \& Purkey, W. (1993).The preparation of humanistic teachers for next century schools. The Journal of Humanistic Education and Development, 30, 147-155.

Rogers, C., \& Freiberg, H. (1994). Freedom to learn (3rd ed.). New York, NY: Maxwell Macmillan International.

Rodgers, C., \& Scott, K. (2008). The development of the personal self and professional identity in learning to teach/ In Cochran-Smith, M. and Feiman-Nemser Sh., (Eds.) Handbook of Research in Teacher Education. Mahway, NJ: Lawrence Earlbaum, 1, 732 - 755.

Samuels, P. (2013). 20th-Century Humanism and 21st-Century Technology: A Match Made in Cyberspace. English Teaching Forum, 3, 2-19.

Stephens, G. (2015). Uncertified and teaching: Industry professionals in career and technical education classrooms. International Journal for Research in Vocational Education and Training, 2(2), 119-135.

Статтю подано до редколегії 08.02.2019 p.

Рекомендовано до друку 28.02.2019 p. 